\title{
THE ECOLOGY OF MOTOR DEVELOPMENT IN COASTAL SCHOOL CHILDREN OF BRAZIL NORTHEAST ${ }^{\mathrm{a}, \mathrm{b}}$
}

\author{
Francisco Salviano Sales Nobre ${ }^{1}$, Mônia Tainá Cambruzzi Coutinho², Nadia Cristina Valentini²
}

DOI: dx.doi.org/10.7322/jhdg.88910

\begin{abstract}
Background: The prevalence of motor delays (MD) in schoolchildren is an intercultural phenomenon which is particularly present among socio-economically disadvantaged children. Objective: to describe and explain the proximal processes for the development of fundamental motor skills (FMS) in schoolchildren from an elementary school (ES) in a coastal city in the Northeast of Brazil. the objective of this study was to describe and explain the proximal processes for the development of fundamental motor skills (FMS) in schoolchildren from an elementary school (ES) in a coastal city in the Northeast of Brazil. Methods: This was a quali-quantitative study. The quantitative aspect was characterized by the use of the Test of Gross Motor Development Edition 2 to evaluate the fundamental motor skills of 104 children from 7 to 10 years old, 56 boys ( $8.2 \pm 1.0$ years) and 48 girls ( $8.3 \pm 0.9$ years). Regarding the qualitative aspect, the researcher ecologically placed himself in the context and used non-systematic and non-participant observations and interviews with 7 parents, representing the parents-board of the school, 7 Physical Education teachers and 11 classroom teachers from different schools. Data analysis: the qualitative data were organized using the content analysis synthesis. The quantitative data were treated using descriptive statistics (mean, standard deviation, distribution and frequencies) and inferential statistics (Student t-test). Results: The results revealed that $95.1 \%$ of children present MD in locomotor skills and $81.7 \%$ in object control skills; girls showed poorer performance compared to boys $(p<0.001)$. Considering the Bioecological model the MD can be explained by the absence of physical infrastructures and material resources, lack of opportunities and poor teacher training. However, the main explanation was the absence of a pedagogical program to foster MP in schools and youth sports programs. Yet, the Bioecological model allowed us to establish that the MP interferes the way that children interact with the context. Conclusions: It can be inferred that part of the solution to the problem lies in the coordination of exosystem actions (Municipal Department of Education) and in changes to the macrosystem (educational legislation) which guarantee the microsystems (schools and social sports projects) the means to promote MP in children.
\end{abstract}

Key words: child development, psychomotor performance, motor skills, motor delays, bioecological model.

1 Laboratório de Crescimento e Desenvolvimento Motor Humano - LACREDEM. Grupo de Estudos em Desenvolvimento Motor \& Saúde da Criança e do Adolescente. Instituto Federal de Educação, Ciência e Tecnologia do Ceará - Campus Juazeiro do Norte, Ceará.

2 Study Group on Motor Evaluation and Intervention School of Physical Education / Federal University of Rio Grande do Sul.

This work had the financial support of the Coordination for the Improvement of Academic Staff (Coordenação de Aperfeiçoamento de Pessoal Docente-CAPES) through providing scholarships at doctoral level (PIQDTec) and, financial support from the Ministry of

a Education /Sesu/PROEXT no. 4/2011/ SIGProj no. 78454.394.29047.16042011. This article was based on the Thesis entitled: Motor development in context: contributions from the

b bioecological model of human development, put forward in October 2013 in the Postgraduate Program in Human Movement Science from the Federal University of Rio Grande do Sul.

Application of the Article: Motor delays. A problem which contributes to sedentary behavior, and therefore, social isolation and development of hypokinetic disorders in children and adolescents.

Corresponding author: salvianonobre@gmail.com

Suggested citation: Nobre FSS, Coutinho MTC, Valentini NC. The ecology of motor development in coastal school children of Brazil northeast. 24(3): 263-273.

Manuscript submitted May 18 2014, accepted for publication Oct 212014. 


\section{INTRODUCTION}

A phenomenon which has puzzled human movement scientists concerns the prevalence of motor delays detected in school. This phenomenon manifests itself regardless of socioeconomic class ${ }^{1,2}$, being, however, more prevalent among children at social risk ${ }^{1,3}$ including those assisted by social programs $^{4}$.

It is assumed that part of the explanation for this phenomenon can be addressed in studies which consider the inseparable relationship established between the individual and the context. In particular, the Person-Process-Context-Time (PPCT) model proves to be robust in meeting this perspective as demonstrated by Bronfenbrenner and Morris ${ }^{5}$, p. 794:

The central element of this model is the Process. More specifically, this construct involves particular forms of interaction between an organism and the environment, named proximal processes, which operate over time and are recognized as the primary mechanisms which cause human development. However, the power of such processes to influence development varies substantially as a function of the characteristics of the person, the immediate and remote contexts and the time periods in which the proximal processes occur.

In the PPCT model, the immediate environments in which the child actively participates are the microsystems (for example, school, social sports projects, community); the social network formed between the microsystems is defined as the mesosystem; remote environments in which, although the child does not actively participate, their development is affected by decisions made within them, are called the exosystem (e.g., Department of Education, Department of sport etc.). Finally, the larger context, defined as the macrosystem is formed by the microsystems mesosystems and exosystems characteristic of a culture or subculture, which reveal the system of beliefs, resources, opportunity structures, risks, social interactions, life styles and choices which are incorporated in each of these systems. What happens in the exo, meso or microsystem can be influenced by this larger context ${ }^{6}$.

From the perspective of the PPCT model, Bronfenbrenner ${ }^{6}$ suggests that the characteristics of an individual at any given moment in their life are a product of the characteristics of the person and the environment throughout their lifetime until that moment. Such traits may present themselves either positively or negatively and can affect the power and direction of the proximal processes over the course of the individual's life ${ }^{5}$.

In particular, three characteristics of a person can affect their development: resources, which refer to the skills, experience and knowledge necessary for the effective functioning of the proximal processes; provisions, which are motivational characteristics that can put the proximal processes in motion in a specific development domain and sustain its functioning; and demand, a characteristic that invites or discourages reactions from people in the social environment, which may facilitate or hinder the operation of proximal processes. These characteristics interact; acting on the strength and direction of the proximal processes ${ }^{5}$.

The Fundamental Motor Skills (FMS) are considered the ABC of movement ${ }^{1}$. Thus, for example, just as an illiterate child cannot read and write, a child who does not know how to run, jump or throw, for example, is also considered motorically illiterate 4 . Among the personal resources of a child, the FMS have the potential to interfere in the way they relate to the context, since these skills are considered prerequisites for participation in physical culture activities (sports, fights and dances) ${ }^{1}$. Understanding how proximal processes work to develop FMS in the microsystem and how this is influenced by more remote environments (exo and macrosystems) is of fundamental importance for the development of physical education, sport and leisure public policies. Thus, the objective of this study was to describe and explain the proximal processes for the development of fundamental motor skills (FMS) in schoolchildren from an elementary school (ES) in a coastal city in the Northeast of Brazil.

\section{METHODS}

This was a study of mixed qualitative and quantitative methodology. The qualitative element met the following characteristics of ethnographic research 7 : a) emphasis on the exploration of the nature of a particular social phenomenon; b) no subordination in the group of analytical categories and $c$ ) a detailed investigation of a case. Thus, the researcher employed the methodological proposal of ecological engagement in the community $^{8}$, where he lived for five months in order to carry out the study.

In terms of human development research, the study lies in the process-person-context-time (PPCT) design. This model suggests that the researcher systematically investigates information in four specific areas: (1) the context in which development occurs, (2) the personal characteristics (biological and/or psychological) of the individuals present in this context, (3) the process through which development occurs, and finally, (4) times, through analysis of chronological time (develop-mental stage of the child) and the effect of socio-historical time in this process. In addition, the researcher is concerned with the bidirectional effects between the person and the context ${ }^{5}$.

In compliance with the PPCT model this study adopted the following procedures: to characterise development, Motor Proficiency (MP) was assessed through the Test of Gross Motor Development 2 TGMD $2^{9}$, validated for the Brazilian population ${ }^{10}$. The TGMD 2 is an instrument oriented in a process which, based on filming, enables the description of qualitative characteristics in the performance of six locomotor skills - SLOC (running, galloping, hopping, long jumps, horizontal jumps and running horizontally) and 6 object control skills OCS (pass, bat, catch, kick, throw up and down a ball). 
The contexts, as well as their interconnections, were identified through the description of the characteristics of the elements which composed the macrosystem. Thus when addressing the structures of opportunities and resources, we obtained information about the microsystem; when investigating the social exchanges, styles and life choices, we obtained information about the mesosystem. In this set of elements we identified how the exosystem acted on the micro and mesosystems. The identification of the risks and belief system provided more specific information about the macrosystem related to physical education, sport and leisure. The identification of the proximal processes took place through the investigation of how the activities to promote FMS were tendered and performed in the microsystems. Finally, time was analyzed in two ways: the effects of the passage of time on children's motor development motor development of the children, i.e., the chronological time which guides expectations as to the desired level of FMS for the children's age group the age group of the children and the socio-historical time which involves facilitating or inhibiting actions for the development of FMS.

\section{Socioeconomic characteristics of the context:}

The city selected to conduct the study is located in the North West Coastal Region of Ceará. The municipality in question has 61,158 inhabitants, of which $74.23 \%$ live in urban areas. The public administration, together with the commercial and service sector accounts for $77.4 \%$ of formal employment. The per capita household income of less than half the minimum wage corresponds to $63.8 \%$ and, between $1 / 2$ and 1 minimum wage to $20.7 \%$. Furthermore, $28.51 \%$ of the economically active population, which was the object of this study, presents a per capita monthly household income of up to $\mathrm{R} \$ 70.00$, which classifies them as extremely poor $^{11}$.

\section{Participants:}

At time of the study 2,991 children attended elementary school (ES) in the urban network; the motor skills of 104 children aged between 7 and 10 years, were evaluated, 56 boys ( $8.2 \pm 1.0$ years) and 48 girls ( $8.3 \pm 0.9$ years). To obtain information about the contexts and proximal processes, 7 Parent Representatives together with the School Board from their respective schools ( 6 mothers and 1 father), 7 physical education teachers ( 5 men and 2 women) and 11 classroom teachers (10 women and 1 man) from different schools in the city were interviewed. A Free and Informed Consent form was signed by parents, teachers and students who agreed to participate in the study. The study was approved by the Committee of Ethics in Research from the Federal University of Rio Grande do Sul Process no. 19861.

\section{Study of macrosystem elements:}

An observational study was performed with on-site visits to all the schools in the county that offered EEI and all institutions offering Social Sports
Projects (SSP). After that, characteristics of the physical infrastructure and material resources for motor practices were recorded in a field diary.

Questions were developed focusing on the macrosystem elements (risk, opportunity structures, resources, life options, lifestyle, social interchanges and child systems) to understand the interconnection with the micro, meso and exosystems; the questions were evaluated by three $\mathrm{PhD}$ teachers in Motor Development and experts in the Bioecological Model. Some questions were asked only to the parent representatives (PR), others only to the classroom teachers (CT), or only to the physical education teachers (PET), while some questions were put to more than one group ( $P R$, CT, PET).

\section{Methodological procedure of the interviews:}

The interview procedure proposed in this paper was based on the Analysis of the collective subject discourse (CSD) ${ }^{12}$. The CSD refers to a methodological proposal for the organization and tabulation of qualitative data of a verbal nature. For this, the authors proposed the use of the following methodological approaches: Key Expressions (KE), which are excerpts or literal transcriptions of speech which reveal the essence of the testimony; Central Ideas (CI), which is a linguistic expression that describes more succinctly the meaning of each discourse and Anchors (AC), which correspond to an explicit linguistic manifestation of a given theory, ideology or belief that the respondent professes to. The interviews were recorded using a digital voice recorder DVR 2926.S Powerpack ${ }^{\circledR}$, and then transcribed for analysis.

A summary table providing guidance on how all the elements of the PPCT model were included in the study is presented below:

\section{Data analysis}

Qualitative data obtained through the field diary and interviews were organized by means of the synthesis of content analysis? ${ }^{7}$. The quantitative data were analyzed using descriptive statistics (mean, standard deviation, frequency distribution) and inferential statistics (Student t test). All information was then interpreted in the light of the Bioecological Model.

\section{RESULTS}

\section{Motor development}

Delays in fundamental motor skills (FMS) have been detected in different cultures. ${ }^{3,4}$ This phenomenon suggests the need for this information to be raised, taking into consideration the context and gender of the child for the development of more effective public policies. Table 1 presents the motor performance characteristics of all the children in the study according to gender:

According to the normative data established in the TGMD $2^{9,10}, 95.1 \%$ and $81.7 \%$ of the children were below the 5 th percentile for locomotor skills (LOCS) and object control skills (OCS), respectively 
which classified them as having motor delays (MD). The children in this study presented scores well below those required for the average of their ages, which is 42 points for LOCS, in both genders, and 42 and 38 points for OCS in boys and girls, respectively. A statistically significant difference was observed only for OCS in favor of the boys.

Table 1: Synthesis of the Bioecological study of motor development - Ceará - Brazil - 2013

\begin{tabular}{|c|c|c|}
\hline Object of the study & Methods & Instrument \\
\hline \multicolumn{3}{|l|}{$\begin{array}{l}\text { Characteristic of the person } \\
\text { under development: }\end{array}$} \\
\hline $\begin{array}{l}\text { Study of the microsystem } \\
\text { Structure of opportunitiesResources } \\
\text { for motor practices }\end{array}$ & $\begin{array}{l}\text { Non-participatory Systematic Ob- } \\
\text { servation and Interview }\end{array}$ & $\begin{array}{l}\text { Field diary and Collective Subject } \\
\text { Discourse }\end{array}$ \\
\hline \multicolumn{3}{|l|}{$\begin{array}{l}\text { Study of the mesosystem } \\
\text { Social interchanges, Lifestyles and } \\
\text { options }\end{array}$} \\
\hline \multicolumn{3}{|l|}{$\begin{array}{l}\text { Study of the exosystem } \\
\text { Actions of the Department of } \\
\text { Education, Sport and Social Action to } \\
\text { create opportunities for motor } \\
\text { practices. }\end{array}$} \\
\hline \multicolumn{3}{|l|}{$\begin{array}{l}\text { Study of the macrosystem } \\
\text { Risks and Belief Systems related to } \\
\text { Physical Education, Sport and Leisure } \\
\text { Analysis of legislation which guides } \\
\text { actions in the exosystem to create } \\
\text { opportunities for motor practices in } \\
\text { the microsystem }\end{array}$} \\
\hline $\begin{array}{l}\text { Analysis of Proximal Processes } \\
\text { Identification of didactic and } \\
\text { pedagogical procedures used in the } \\
\text { microsystem }\end{array}$ & $\begin{array}{l}\text { Non-participatory Systematic Ob- } \\
\text { servation and Interview }\end{array}$ & $\begin{array}{l}\text { Field diary and Collective Subject } \\
\text { Discourse }\end{array}$ \\
\hline $\begin{array}{l}\text { Analysis of the Time Element } \\
\text { Chronological Time }\end{array}$ & $\begin{array}{l}\text { Analysis of Gross Motor Develop- } \\
\text { ment }\end{array}$ & $\begin{array}{l}\text { Test of Gross Motor } \\
\text { Development (TGMD 2). }\end{array}$ \\
\hline \multirow[t]{2}{*}{ Socio-Historical Time } & Interview & \\
\hline & Bibliographical Research & $\begin{array}{l}\text { Collective Subject } \\
\text { Discourse Bibliographical } \\
\text { Research }\end{array}$ \\
\hline
\end{tabular}

Table 1: Motor performance: mean, dispersion, and comparison between sexes

\begin{tabular}{lccccc} 
Motor Performance & \multicolumn{2}{c}{ Masculine } & \multicolumn{2}{c}{ Feminine } \\
& Min - Max & M(SD) & Min - Max & M (SD) & $P$ \\
Gross score LOC & $(10-34)$ & $24,0(5,5)$ & $(13-35)$ & $23,2(5,1)$ & 0,418 \\
Gross score CO & $(12-40)$ & $26,7(6,0)$ & $(08-34)$ & $22,2(6,0)$ & $0,001 *$
\end{tabular}

Gross Score LOC: Gross Score Locomotor; Gross Score OC: Gross Score Object Control;

* Significant differences for $\mathrm{p}<0.05$ : t-test for independent samples.

\section{Study of the context:}

\section{1) Physical structure for motor practice}

The way a physical space is organized cannot be ignored in the process of the acquisition of motor skills ${ }^{14,15}$. In Figure 1, the geometric design of the triangle refers to the presence of schools offering Elementary Education I (EEI); the empty circles represent the presence of minimal physical infrastructure; the filled circles, the presence of adequate physical infrastructure ${ }^{1}$ and the pentagons social support units².

In the city studied, the prevalence of physical infrastructure was found to be nonexistent for motor driven practices in schools that offered Elementary Education I (EEI). Only one school presented adequate physical infrastructure. The vast majority of schools were devoid of spaces to hold physical 


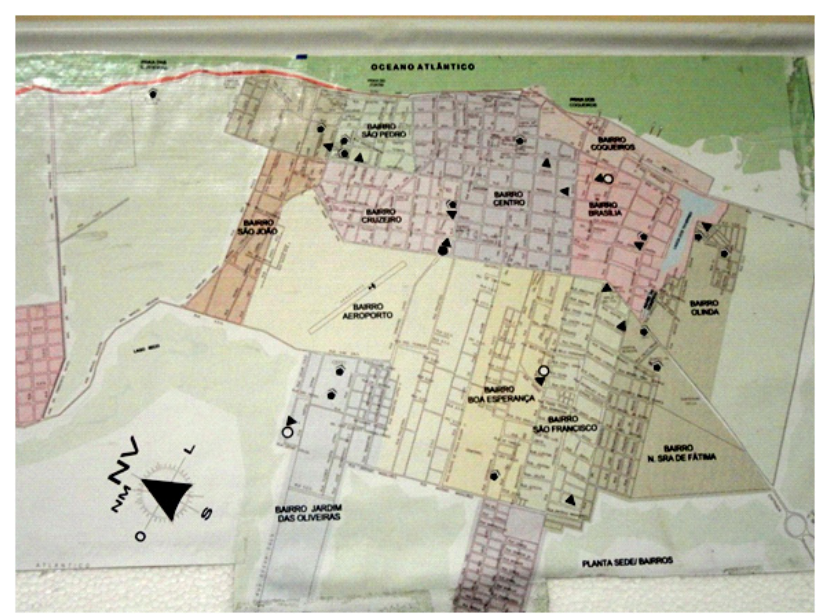

Figure 1: Map of the physical spaces available for motor practice

education (PE) classes. Heterogeneity was also found in the distribution of social support units. It is worth noting that observational research established that the few public spaces which existed for motor practice were in a state of total abandonment as illustrated in Figure 2.

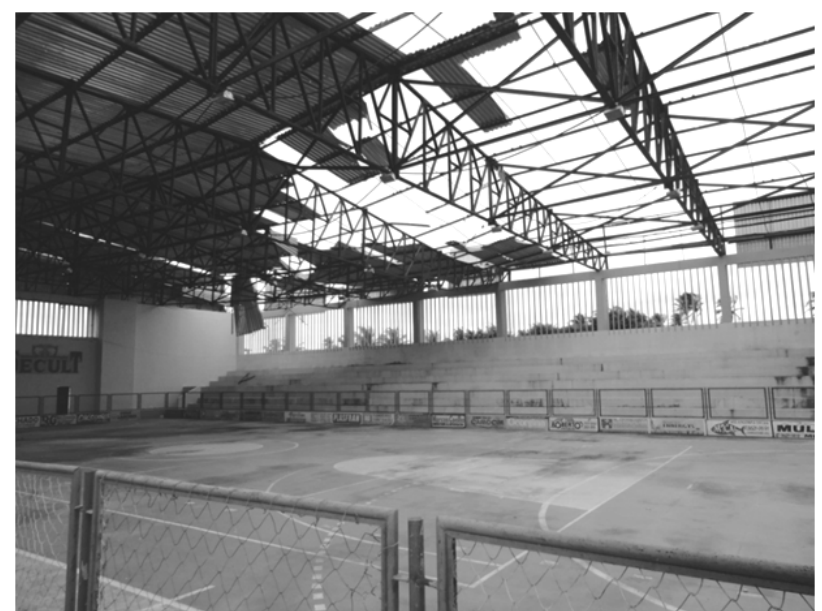

Figure 2: Conservation Status of Municipal Gymnasium

The observational study also revealed the existence of social support units very close to some schools. However, these spaces were not used by the schools to develop PE classes. The study showed, at that time, the existence of 6 social projects, none of which originated from the Ministry of Education and Sport. Of the 6 social projects, only 3 made use of motor practice in their educational approach, and in all of them the activities had been developed by monitors without training in pedagogy or PE.

\section{2) Risks in limiting factor for motor practices}

Among the urban problems in contemporary times, violence presents itself as one of the principle contributors to the loss of child autonomy. When the parent representatives were asked if violence constituted an inhibiting or limiting factor for motor practices, they tended to say no. In fact, the ecological integration of the researcher into the community ${ }^{8}$ allowed him to establish that in general the municipality where the study was developed was not violent. The Collective Subject Discourse (CSD1.1), referred to the fact that parents who resided in only two districts considered them to be violent, confirming what had been identified through observation.

\section{CSD 1.1}

\section{AC: the violence is associated with the} formation of gangs and drug trafficking.

I do not have confidence to let my son play alone in the street. There are sometimes fights here, there are people who come here from other streets to fight and this fight is because of drugs. Also the children are very aggressive, they form gangs, and then, because of this, it is dangerous for the other children who do not join. So I do not let my daughters go out to play.

\section{3) Opportunities for motor practice in the microsystem}

When questioning PE teachers (CSD 2.1) and classroom teachers (CSD 2.2) on the existence of PE classes in elementary education (EEI), only convergent discussions were recorded. The lack of commitment by the government towards PE classes in EEI was explicit in both the CSDs.

\section{CSD 2.1}

AC: Physical Education classes are designed by classroom teachers who feel that they are unprepared and compromise the motor development of the children.

I believe it is common knowledge that the classroom teachers can take physical education classes. Unfortunately, this is in the whole city and I believe in other cities also. I would like to emphasize that this is making these children a huge disservice. Many of them, when they get arrive in the 6th year, are totally uncoordinated. They are unable to perform any of the more specific movements, precisely because they did not have a consolidated basis. Furthermore, they have impaired emotional development, because many children are isolated and feel ashamed that they do not know how to play.

CSD 2.2

Well, I believe that there is a scheduled time for physical education in all schools, but it is not physical education as such. Every week we record it, but it does not happen every week, because, for example, we have students who are in the $4^{\text {th }}$ year, but, the majority are actually at the level of the $1^{\text {st }}$ year. So we push more toward developing reading and writing, and end up taking the physical education class time for this. It's very complicated, and we are not even prepared to teach physical education. It is a very distressing situation. Seriously, I do not like it! There should be training so that we can be prepared or there could be a teacher specializing in physical education to work with the children.

4) Content explored in Physical Education classes and material resources available.

When asked which subjects were explored in PE classes and the materials available, the teachers 
reported a lack of material resources and, even more prejudicial, the lack of a didactic-pedagogic proposal to promote the motor proficiency (MP) of children.

\section{CSD 3.1}

CI: the content of physical education classes is restricted to recreational and dynamic activities and material resources are nonexistent.

The school does not have space, so we develop group dynamics which can be done in the classroom itself. When we have space we do more recreational activities, even games and sports. The boys prefer ball games and the girls, volleyball. We do not know if the classes are well planned because we are not trained in this area and have never had targeted training for physical education. I have never received material resources for my classes. None!

\section{5) Life choices in the mesosystem.}

When the parent representatives were asked about what other life choices beyond school were offered to the children in the neighborhood, there was the presence of conflicting discussions, confirming what had already been displayed in Figure 1: the presence of more than one unit of social support in some neighborhoods and the complete absence in others.

\section{CSD 4.1}

CI: The lack of life choices is associated with a non-existent physical infrastructure.

That's complicated! Because, well, I do not see options for the children. It is they themselves who make little groups and play ball in empty fields. It would be great if there was a recreational center or a school where we could put the children to play sports, to make sure that someone was looking after them. I think it depends on our government; they have to see this side, reevaluate what the children need, and do it.

\section{CSD 4.2}

CI: There are life choices, but they lack public interventions for their effective functioning.

There is a residents' association, the ABC Project, and an non-governmental organization. For the children who study in the morning, there is the afternoon and for those who study in the afternoon, the morning. There they have music and dance lessons and school reinforcement, but there are no sports. For sports there is only the $A A B B^{c}$ and $C R A S^{d}$. The gym is only for the older boys. I think they ought to look more at children here in the neighborhood, these authorities; they are elected and then are never seen again around here.

\section{6) Children's lifestyle}

When the parent representatives were asked about how the children occupied their free time, the CSD 5.1 revealed an interconnection between the elements that compose the macrosystem. Life choices are related to the underlying physical infrastructure and the opportunities offered which influence the lifestyle of the children. Furthermore, the CSD 5.1 revealed a trend towards loss of cultural identity games which make use of extensive motor skills.

\section{CSD 5.1}

CI: The lifestyle of the children is linked to life options.

Many of the mothers work as house cleaners in other houses and the children are left free on the street. Some are in a project, for others, their leisure is sitting in front of a TV or playing video games. The games they play are the ones I know; catch, cops and robbers, ball games, marbles, sling shot, flying kites... But what I see most is playing ball on the sidewalks for lack of suitable locations.

The observational research enabled us to establish that the activities carried out in social sports projects (SSP) were restricted to football for boys, dance for girls, recreational activities for both genders and capoeira for some children. It was observed therefore that the mesosystem formed by the school and SSP microsystems proved to be weak in material resources and in the structuring of content to promote FMS, mainly object control skills.

\section{7) On policies of social interchange}

Still with the objective of knowing how the children used motor proficiency (MP) to interact with the context, we asked the physical education teachers how sports or games were used to promote social interaction. This question generated a CSD which pointed to the existence of a consolidated event in the macrosystem, but with little support from the exosystem; Department of Sports / City Hall.

\section{CSD}

AC: social exchange occurs only through competitive activities, with little encouragement from the exosystem, and only includes the most skilled

We had the school Olympics. It was an event that happened in the months from October to December. Every weekend. Actually organized by the local government! It was a project that was generated with the students of Physical Education. But the children from the $1^{\text {st }}$ to $5^{\text {th }}$ year did not have this experience because they had no physical education teacher who could accompany them and train them for the competition. It happened five times, but unfortunately due to lack of public policies it hasn't happened since last year. It is a loss because the students liked to play, have fun and socialize with different people. 


\section{8) On the belief system related to PE, sport and leisure.}

It is suggested that the identification of the belief system as an element of the macrosystem in the PPCT model5,6, appears to be able to provide some explanation as to how important an activity is considered in the micro and exosystems. Under this rationale, we elaborated the following impact sentence with parents and classroom teachers: "Now, I am going to say a sentence and want to know if you agree or disagree and why. The sentence is as follows: there should be no more physical education classes in school."

The reaction of the classroom teachers was unanimous on the importance of physical education $(P E)$ on the formation of children. However, the parent representatives raised divergent discussions.

CSD 7.1 (Classroom Teachers).

AC: it is important to have physical education classes, but with a qualified professional

I disagree! The physical education classes promote not only good health of the body, but also interactivity and collectivity. It is important for the intellectual and physical growth of the child. It is also a way for children to use a little accumulated energy which can sometimes even make them violent. It is very good for their formation to know that there are rules and these rules must be respected. Because of this I think it is necessary, but in a more serious way, with a truly qualified person from the same professional area, which is not our case.

CSD 7.2 (Parent Representatives).

CI: You have to have them because it is necessary and good for health

I disagree; we have to have the classes because I think it is necessary. It will help the child to grow and develop a part of the brain that helps them pay more attention in class. The children spend 4-5 hours in the classroom, that moment of physical education is the time they have to let their energy out. They have to have that moment to have fun, but it must be appropriate and the teachers have to accompany them properly.

CSD 7.3 (Parent Representative).

CI: if physical education is just playing ball, it is better not to have it

I agree, because I disagree with the classes they are having today, they just go out there to play ball and end up with injuries. A specialist teacher is necessary for each sport, the classes need to be longer and be given more attention and thought, because it's just a little thing, playing ball and then going home. If it is going to be like this, I think there's no need to have it, no!

Still on the belief system, the following problem was put to the physical education teachers: "Now, I am going to say a sentence and ask you to complete it. The phrase is: physical education classes and social sports projects will only really be recognized as important by society when..."

The need for changes in the macrosystem and in the physical education teachers themselves was evident in CSD 8.1, in order for physical education to have more credibility in society.

\section{CSD 8.1 .}

CI: when there is seriousness and commitment from the government and the teachers themselves

When the municipal, state and federal government stops talking and actually does something. There will be more recognition of the professionals. Serious public policies which develop projects and enable the development of professionals both at school and in the community are needed. But also, when teachers begin to change their own minds and fight for this recognition. We have this difficulty because there is no proposed curriculum for schools, the physical education teachers just do what they want. I believe that if the content were systematized to be only one thing to be worked on in all schools physical education would have more value.

\section{DISCUSSION}

The prevalence of motor delays (MD) found in this study in economically disadvantaged populations was consistent with studies conducted in Brazil $^{3}$ and abroad ${ }^{1,4}$. However the MD of the children in this study was more pronounced. There is evidence that socioeconomic status affects fundamental motor skills (FMS) more than other factors such as race, ethnicity and geographic regions ${ }^{1}$. It is known that characteristics of gender have the potential to influence motor proficiency (MP) in children ${ }^{3,4}$, however, it is understood that the opportunities offered in the context are what most determines the highest levels of MP.

The most compromised performance in object control skills (OCS), especially in girls, deserves special attention. The OCS domain in childhood is accepted as a predictor for participation in free and/ or organized motor practices in adolescence ${ }^{13}$. One characteristic of personal stimulus as "demand", for example gender, cannot go unnoticed, since the opportunities for development are not always equal for boys and girls ${ }^{16}$.

The absence or insufficiency of sports facilities has also been observed in other Brazilian contexts ${ }^{14,15}$, being aligned with socioeconomic status and income distribution. Physical Education in school faces similar problems in different contexts in Brazil, which reflects the need for guidance on the public policies in the macrosystem to address such problems ${ }^{15}$.

The precarious conservation of public spaces is part of the urban scene, and it can be seen that the public squares and playgrounds, are victims of abandonment by public power, and are often used for illicit purposes ${ }^{17}$. The development of FMS requires a minimum of physical infrastructure and material resources. Furthermore, there is evidence 
that the way in which the physical infrastructure of the macrosystem is organized influences the preferences of the local population and consequently the performance of activities ${ }^{18}$.

By noting that some existing public physical infrastructures were not used to serve the interests of the schools, the study revealed a complete dislocation in the exosystem (Department of Education, Department of Sports and Social Action Secretariat) to meet the needs of promoting MP in children. According to the literature, contexts that do not nurture interaction between the child and the environment tend to disfavor the generative rules that drive the motor development of children ${ }^{18}$.

The types of violence varies between countries, regions, cities and geographic units, and, despite violence being concentrated mainly in metropolitan areas, studies point to the internalization of violence associated with the use and trafficking of drugs ${ }^{19}$, as was also reported in this study. Although poverty does not justify violence, it is an aggravating factor in the practice of violence; in this study it was found that the two neighborhoods considered most violent were on the outskirts of the city, where most of the population classified below the poverty line was concentrated.

It is necessary to invest in public policies which guarantee security in appropriate locations for children to play and result in motor opportunities for children. This way, parents can feel safe and empower their children to explore the environment during their free time and thus develop adequately ${ }^{18}$.

The CSDs 2.1, 2.2 and 3.1 made explicit how the proximal processes for developing FMS were triggered and sustained in the school microsystem. The discussions showed the nested system highlighted by Bronfenbrenner ${ }^{6}$, where what occurs in the school microsystem is influenced by the decisions that are made in the exosystem (City Hall /Department of Education). In turn, this lack of connection between the exo and the microsystem is influenced by the macro system which determines the Laws which do not guarantee the operation of school physical education in EEI.

Despite the fact that item III of Art. 26 of Law 9.394/96, of the Directives and Bases of Education (DBE) determines that: "physical education, integrated into the school pedagogical proposal, is a mandatory curriculum component of basic education (...)" (BRAZIL 20,2010, p. 3), the law does not establish the number of physical education classes for each education cycle. Soon after this, the Resolution of the Ceará's Education Board 412/200621, supporting the gaps in the DBE 9.394/96, determined that the physical education classes in EEI be assigned to the classroom teachers and the treatment to be given to physical education should be spelled out in the school pedagogical proposal, detailing the number and duration of sessions.

What occurs when such a requirement established by law is linked to the interests of the school pedagogical proposal is that the exosystem (Municipal Department of Education) does not guarantee that students from the $1^{\text {st }}$ to $5^{\text {th }}$ year of EEI have physical education classes as evidenced in CSD 2.2. In other words, the discipline exists only for legal effect.

Since the macrosystem gives classroom teachers the responsibility for developing PE classes, it is expected that the same would guarantee training, and/or even consider the provisions thereof to assume this responsibility, however, this seems to be minimal, as mentioned in CSD2.2. In this sense, considering that federal legislation does not necessarily ensure the rights provided to education in its broadest form ${ }^{22}$, it appears that a state law similar to that which occurs in the State of São Paulo $^{23}$, is crucial for these purposese.

The lack of physical infrastructure and material resources reported in CSD 3.1 is responsible for the proximal processes appearing negative, given that the absence of objects to be exploited and manipulated inhibits the attention and imagination of the students, making it difficult, therefore, for reciprocal interaction to occur ${ }^{5,6}$. However, it is suggested that the reported lack of teacher training in CSD 3.1 tends to be more pernicious than these other two factors.

The continuous training of teachers, including specialists, is needed to promote motor development. Research conducted with children of high socioeconomic status in Porto Alegre, RS, Brazil, aged 5 and 6 years, who had physical education classes, in addition to extracurricular motor practices taught by PE teachers and performed 2-5 times per week, also showed prevalence of motor delays ${ }^{2}$. However, one should consider that these children were being given opportunities. What needs to be reviewed is how proximal processes develop in microsystems. Equally important as the frequency of activities mentioned above, is knowing whether children are engaged in activities, if there is progress regarding the complexity of the activities, if the activities allow the child's involvement with objects and symbols stimulating manipulation, attention, exploration and imagination, and if there is reciprocal interaction between children-teachers and children-children ${ }^{5,6}$.

The teacher's pedagogical practice through exploration of the content and material resources available reveals how proximal processes are operated to promote FMS. The observational study and the CSD 3.1 reveal that teachers qualify their teaching primarily as recreational. While $\S 1^{\text {st }}$ of article Art. 6 of CEC Resolution 412/2006 ${ }^{21}$ suggests that physical education classes should be offered in EEI in the form of recreation, research suggests that playing for the sake of playing, albeit in an enriched environment with material resources, does not promote MP; the mediation of the teacher being crucial in this process ${ }^{24}$.

In relation to the community microsystem, CSD 5.1 reveals that the games that persisted in

e In the State of São Paulo, Resolution 173 of $5^{\text {th }}$ December $2002^{23}$ establishes the obligation of physical education classes in all grades, twice a week to be taught by physical education teachers, assisted by classroom teachers. 
the local culture required more fine than gross motor coordination (marbles, sling shot, kite). It was also possible to observe the little involvement of girls in play in the community. Research reveals sexual segregation and lack of equal play opportunities during childhood ${ }^{25}$. This fact may also contribute to the higher prevalence of motor delays in females ${ }^{3}$, which suggests that more options for motor practice should be guaranteed to the girls in school and SSP microsystems, since when stimulated, children in EEI exhibit greater identification with motor classification play ${ }^{25}$.

By identifying how the MP of a child affects their social interchange we end up with a unidirectional vision of development in which the context directs the development of the child. As explained by Bronfenbrenner and Morris (2007) ${ }^{5}$, the characteristics of a person are either products or producers of development. The study revealed that the FMS of children is influenced by the contexts (micro-meso-exo and macrosystem), whereas personal resources are channeled to motor actions across the different microsystems. The personal characteristics of the child reflect therefore on the way the context is experienced by them as well as on the types of contexts at which they are directed ${ }^{16}$.

CSD 6.1 revealed that only children with better MP had opportunities for social interchange. It's clear that the MP of the child guides their goals and provisions and leads to the demands of their peers, affecting the way they deal with the developing child, and with the goals, values and expectations they have towards the child. Skillful children present this feature as a facilitator of interaction as they have more opportunities to lead, particularly in activities in which their superior abilities prove resolute 26 .

Regarding the belief system involving physical education, sport and leisure, this study suggested that parents, classroom teachers and school administrators recognize the importance of physical education classes in the early grades, however, the discussion showed itself to be divorced from practice $^{27}$. On this subject, Molina Neto ${ }^{28}$ (2003) states that this fact happens due to the emphasis of the Brazilian social project being focused on economic development and, thus, giving more importance to intellectual knowledge, leaving attitudinal and procedural content in the background.

In this sense, it must be noted that proximal processes will only become more positive according to the significance value which society places on this type of skill, since it clearly depends on their beliefs and objectives ${ }^{22}$. Thus, for example, parents and teachers will be more likely to equip the children with the kinds of skills that they deem to be more essential for them ${ }^{16}$.

The reductionist view that society has physical education by associating it merely to sports, and particularly football, is built within socio-historical time. Whilst PE teachers criticize the macrosystem as the principal responsible for their poor professional development ${ }^{28}$, they assume, selfcritically, the dilemma that teachers trained in different historical moments and in different institutions, exhibit similar practices.

This attitude of the teacher refers to the roles highlighted by Bronfenbrenner ${ }^{5}$. According to this theory, the roles need to go beyond the expectations that society has of who plays the role, and incorporate expectations which the individual themselves has regarding what they expect others to expect of them. From this perspective, as claimed in CSD 8.1, vertical integration of the content is crucial for proximal processes to operate positively and for physical education teachers to be valued in society.

An analysis of the Time element in the PPCT Model from a socio-historical perspective shows that the lack of working conditions for physical education teachers in Brazil carries with it historical roots dating back to the final years of the nineteenth century to the present day ${ }^{14}$. What happens in physical education is just a reflection of what happens in public education as a whole.

The present study proposed an alternative for understanding motor development (MTD) from the bioecological model. It was verified that a developmental characteristic (motor proficiency - MP) is affected by the context, but also acts on its relation with it. In the case of almost $100 \%$ of motor delays (MD) in children, it was found that the MD of the child can be affected by violence in the environment and the belief system of their parents. In this study, the absence of physical infrastructures and material resources, and, most keenly, the lack of opportunities for motor practices and little teacher training were the main factors involved in this process. The analysis of the bidirectional relationship between the child and the context showed that MD affects how children experience the context (games and sports competitions).

From these results, it is reasonable to believe that there is a need to link the exosystem (the City Government Departments) and changes in the macrosystem (Education Law) to guarantee microsystems (School and Sports Projects Social) have opportunities to promote MP. From a more pragmatic point of view, it is essential to adopt a pedagogical approach which does not remain restricted to recreation and contributes to promoting MTD. Vertical integration of the content in elementary education is also crucial. Regarding limitations in this study, it is important to note that the influences of factors such as nutritional status and perceived competence which affect MP were not investigated in this study. Despite this, it is believed that this work presents itself as an advance in the research in the area of Physical Education, breaking with the vision of MTD which usually links the development of the child to a single environment and disregards that the MP of the child also affects the context.

\section{Acknowledgements:}

In memoriam of Prof. Dr. Ruy Jornada Krebs for his relevant contributions made in discussions of Bioecological Theory of Human Development 
during the preparation of the research project that led to this work, and to Prof. Dr. Normanda Araújo

\section{REFERENCES}

1. Booth, ML. et. al. Mastery of fundamental motor skills among New South Wales School students: prevalence and sociodemographic distribution. Aust J Sci Med Sport. 1999; 2 (2): 93-105.

2. Brauner, LM.; Valentini, NC. Análise do desempenho motor de crianças participantes de um programa de atividades físicas. R. da Educação Física UEM. 2009; 20 (2): 205 - 216. http://dx.doi.org/10.4025/reveducfis v20 n2 p 205-216

3. Spessato, BC.; Gabbard, C.; Valentini, NC.; Rudsill, M. Gender differences in Brazilian children's fundamental movement skill performance. early child development and care. 2012; 7 (14): 1 - 8. http://dx.doi.org/10.1080/ 03004430.2012 .689761

4. Goodway, JD.; Robinson, LE.; Crowe, H. Gender differences in fundamental motor skill development in disadvantaged preschoolers from two geographical regions. Res Q Exerc Sport. 2010; 81 (1): 7 - 24.

5. Bronfenbrenner, U.; Morris, PA. The bioecological model of human development. Handbook of child psychology. Department of Human Development, Cornell University, Ithaca, New York, USA, 2007. 793 - 828. http://edfa 2402 resources.yolasite.com/resources / BronfenbrennerModelofDevelopment.pdf. (acesso em 12/07/2012)

6. Bronfenbrenner, U. Ecological systems theory. (In): Bronfenbrenner, U. Making human being human: bioecological perspectives on human development. Thousand Oaks, CA: Sage Publications, 2005. 106 - 73.

7. Flick, U. Introdução à pesquisa qualitativa. $3^{a}$ ed. Porto Alegre: Artmed, 2009, p. 203 - 18.

8. Cecconello, AM.; Koller, SH. Inserção ecológica na comunidade: uma proposta metodológica para o estudo de famílias em situação de risco. Psicol. Reflex. e Crit. 2003; 16 (3): 515 - 524. http://dx.doi.org/10.1590/S0102-797220030 00300010

9. Ulrich, DA. TGMD 2 - Test of gross motor development examiner's manual . 2 ed. Austin, Texas: Pro-ed, 2000. $04-60$.

10. Valentini, NC. Validity and reliability of the TGMD -2 for Brazilian children. J. Mot Behav. $2012 ; 44$ (4): $275-80$.

11. IPECE. Instituto de Pesquisa e Estratégia Econômica do Ceará. Perfil Básico Municipal. Disponível em http://www.ipece.ce.gov.br/ publicacoes/perfil_basico/pbm-2011/. Acesso em 07 de Junho de 2012.

12. Lefevre, F.; Lefevre, AMC. O discurso do sujeito coletivo: um novo enfoque em pesquisa qualitativa (desdobramentos). $2^{\mathrm{a}}$ ed. Caxias do Sul: Educs, 2005, p. 13-57. de Morais for her specific suggestions which added value to this work.

13. Barnett, LM.; Van Beurden, E.; Morgan, PJ.; Brooks, LO.; Beard, JR. Childhood motor skill proficiency as a predictor of adolescent physical activity. J. Adolesc Health. 2009; 44 (3): 252 - 59.

14. Gaspari, TC.; Souza Junior, O.; Maciel, V.; Impolcetto, F.; Venancio, L.; Rosário, LF. et. al. A realidade dos professores de educação física na escola: suas dificuldades e sugestões. R. Min. Educ. Fís. 2006; 14 (1): 109 - 37. http:/ /www.revistamineiradeefi.ufv.br/artigos/ arquivos/7828138ea2673071 ec9aa11cf 361c7ed.pdf . (acesso 09/07/2012).

15. Tokuyochi, JH., Bigotti, S.; Antunes, FH.; Cerencio, M.; Dantas, LEPBT.; Leão Marcos, H.; Tani, G. Retrato dos professores de Educação Física das escolas estaduais do estado de São Paulo. Motriz. Rev. Educ. Fisc. 2009; 14(4): 418 - 28.

16. Tudge, J.; Doucet, F.; Odero, D. Desenvolvimento infantil em contexto cultural: o impacto do engajamento de pré-escolares em atividades do cotidiano familiar. Interfaces Rev. de Psic. 2009; 2 (1): 23- 33.

17. Luz, GM. da; Raymundo, LS.; Kuhnen. Uso dos espaços urbanos pelas crianças: uma revisão. Psicol. teor. prat. 2010; 12 (3): 172 - 84. http:/ /pepsic.bvsalud.org/pdf/ptp/v12n3/ v12n3a14.pdf. (acesso em 06/07/2012).

18. Krebs, R. J.; Carniel, J. D.; Machado, Z. Contexto de desenvolvimento e a percepção espacial de crianças. Movimento. $2011 ; 17$ (1): 195 - 212. http://www.seer.ufrgs.br/ index.php/Movimento/article/view/15483/ 12949. (acesso em 06/07/2012).

19. Souza, E. R. de.; Lima, M. L. C. de. Panorama da violência no Brasil e suas capitais. Ciênc. saúde coletiva. 2006; 11 (supl): 1211 - 22. http: //dx.doi.org/10.1590/S141381232006000500011

20. Brasil. LDB - Lei de Diretrizes e Bases da Educação Nacional: lei no 9.394, de 20 de dezembro de 1996. $5^{\text {a }}$ ed. Brasília: Câmara dos Deputados, Coordenação Edições Câmara, 2010. P. 23. http://www.planalto.gov.br/ ccivil_03/leis/19394.htm. (acesso em 9/07/ 2012).

21. Ceará. Conselho de Educação do Ceará. Resolução 412/2006. Disponível em http:// www.cee.ce.gov.br/phocadownload/ resolucoes/RES-0412-2006.pdf. p. 1 - 3 (acesso em 12/07/2012).

22. Freitas, L. B. L.; Shelton, T. L.; Tudge, J. R. H. Conceptions of US and Brazilian early childhood care and education: A historical and comparative analysis. Int. J. Behav. Dev. 2008; 33 (2): 161 - 170.

23. Silva, E. V. M.; Venâncio, L. Aspectos legais da Educação Física e integração à proposta 
pedagógica da escola. (In): Darido, S. C.; Rangel, I C. A. (Org.). Educação Física na Escola: implicações para a prática pedagógica. Rio de Janeiro: Guanabara Koogan, 2008, p. $50-63$.

24. Palma, M. S.; Pereira, B.; Valentini, N. C. Jogo com orientação: uma proposta metodológica para a educação física pré-escolar. R da Educação Física/UEM. 2009; 20 (4): 529-541. http://dx.doi.org/10.4025/reveducfis v20 n4 p 529-541

25. Cordazzo, S. T. D.; Vieira, M. L.; Almeida, A. M. T. Brincadeiras de crianças brasileiras e portuguesas no contexto escolar. Journal of Human Growth and Development. 2012; 22 (1): 1 - 13. http://pepsic.bvsalud.org/pdf/ rbcdh/v22n1/pt_09.pdf. (acesso em 16/03/ 2014).
26. Miyabayashi, L. A.; Pimentel, G. G. de A. Interações sociais e proficiência motora em escoares do ensino fundamental. Rev. Bras. Educ. Fís. Esporte. 2011; 25 (4): 649 - 63. http://dx.doi.org/10.1590/S180755092011000400009

27. Magalhães, J. S.; Kobal, M. C.; Godoy, R. P. de. Educação Física na Educação Infantil: uma parceria necessária. Revista Mackenzie de Educação Física e Esportes. 2007; 6 (3): 43 52. http://editorarevistas.mackenzie.br/ index.php/remef/article/viewFile/1223/936. (acesso em 06/07/2012)

28. Molina Neto, V. Crenças do professorado de educação física das escolas públicas de Porto Alegre. Movimento. 2003; 9 (1): 145 - 69. http://www.lume.ufrgs.br/bitstream/handle/ 10183/86384/000382577. pdf ? sequence $=1$. (acesso em 09/07/2012).

\section{Resumo:}

Fundamentação: a prevalência de atrasos motores (AM) em escolares é um fenômeno intercultural que atua principalmente em crianças desfavorecidas socioeconomicamente. Objetivo: avaliar a proficiência motora (PM) de escolares da rede pública do Ensino Fundamental I de um município litorâneo da Região Nordeste do Brasil e interpretar o mesmo à luz do Modelo Bioecológico. Método: trata-se de um estudo de abordagem mista, qualitativo e quantitativo. A parte quantitativa do trabalho fez uso do Test of Gross Motor Development Edition 2 para avaliar o desempenho motor nas habilidades motora fundamentais de 104 crianças com idades entre 7 e 10 anos, 56 meninos $(8,2 \pm 1,0$ anos $)$ e 48 meninas $(8,3 \pm 0,9$ anos). Para parte qualitativa, o pesquisador inseriu-se ecologicamente no contexto e fez uso de observação assistemática não participante e entrevistas a 7 Representantes de Pais, 7 professores de educação física e 11 professoras polivalentes de diferentes escolas. Análise dos dados: os dados qualitativos foram organizados mediante a síntese da análise de conteúdo. Os dados quantitativos foram tratados por meio de estatística descritiva (média, desvio padrão, distribuição de frequência) e estatística inferencial (Teste t de Student). Resultados: verificou-se que $95,1 \%$ das crianças apresentaram AM para habilidades locomotoras e $81,7 \%$ para habilidades manipulativas, com maior prejuízo para o sexo feminino nas habilidades manipulativas $(p<0,001)$. A análise dos dados qualitativos à luz do Modelo Bioecológico sugerem que os AM podem ser explicados pela ausência de estruturas físicas e recursos materiais nas escolas, mas, principalmente, pela falta de oportunidades, baixa capacitação docente, e pela inexistência de uma proposta pedagógica para promover a PM tanto nas escolas como nos projetos sociais esportivos. Ainda, o Modelo Bioecológico permitiu constatar que a PM interfere na forma como a criança se relaciona com o contexto. Conclusão: Infere-se que em curto prazo, parte da solução do problema pode está na articulação das ações do exossistema (Secretarias Governamentais do Município) e, que em longo prazo faz-se necessário alterações no macrossistema (Legislação Educacional) que garanta aos microssistemas (escolas e projetos sociais esportivos) possibilidades de promover a PM das crianças.

Palavras-chave: desenvolvimento humano, desempenho motor, habilidades motoras, atrasos motores, modelo bioecológico. 